\title{
Измерение активности растительного покрова
}

П.М. Мазуркин, С.И. Михайлова

Введение. До проектирования мер по комплексному подъему сельских территорий для рационализации отраслей природопользования необходима разработка способов, позволяющих достичь землям к сбалансированному состоянию. Череда состояний дает динамику поведения ландшафтов.

Главным элементом ландшафта является растительный покров.

Активность растительного покрова, то есть экстенсивное изменение его по площади, оказывает прямое влияние на достижение территориального экологического равновесия. Для измерения активности растительного покрова используются данные из земельного кадастра. Однако он пока составляется только по административным образованиям и то только на уровне административных районов субъектов Российской Федерации.

В будущем же, конечно, потребуется составлять также модификации земельного кадастра и в разрезе экосистем (ландшафтов). Тогда появится возможность анализа геотриады «ландшафт + население + хозяйство».

Растительный покров по земельному кадастру. Естественный, частично измененный человеком или же полностью культурный растительный покров (сады, лесные плантации, городские парки и пр.) могут стать фитоиндикаторами [1] на территориальном образовании: ландшафте, водосборном бассейне, административном районе, территориальнопромышленном комплексе, городе или другом населенном пункте.

К растительному покрову следует отнести земельные участки, на которых произрастают растения без последующей пахоты. Поэтому к растительному покрову нельзя относить однолетние и многолетние травы, применяемые в севооборотах сельскохозяйственных культур.

Для измерения активности растительного покрова исходные данные на 01.01.2007 г. по Республике Марий Эл (РМЭ) приведены в табл. 1. 
Таблица 1

Данные земельного кадастра по Республике Марий Эл на 01.01.2007, тыс. га

\begin{tabular}{|c|c|c|c|c|c|c|c|c|c|c|}
\hline \multirow{2}{*}{$\begin{array}{c}\text { Кате- } \\
\text { гория } \\
\text { земель }\end{array}$} & \multirow{2}{*}{$\begin{array}{c}\text { Общая } \\
\text { пло- } \\
\text { щадь }\end{array}$} & \multirow{2}{*}{$\begin{array}{c}\text { Всего } \\
\text { с/х } \\
\text { угодий }\end{array}$} & \multicolumn{5}{|c|}{ В том числе: } & \multirow{2}{*}{$\begin{array}{c}\text { Земли, } \\
\text { покрыт. } \\
\text { лесом }\end{array}$} & \multirow{2}{*}{$\begin{array}{l}\text { Древес. } \\
\text { кустарн. } \\
\text { растит. }\end{array}$} & \multirow[b]{2}{*}{ Болота } \\
\hline & & & Пашни & Залежи & $\begin{array}{l}\text { Мн.лет. } \\
\text { насажд. }\end{array}$ & $\begin{array}{l}\text { Сено- } \\
\text { косы }\end{array}$ & $\begin{array}{l}\text { Паст- } \\
\text { бища } \\
\end{array}$ & & & \\
\hline 1 & 860.3 & 715.9 & 467.4 & 101.7 & 5.3 & 42.8 & 98.7 & 91.0 & 16.6 & 2.3 \\
\hline 2 & 77.1 & 48.1 & 27.3 & 0.8 & 3.0 & 5.9 & 11.1 & 3.2 & 2.5 & 0.2 \\
\hline 3 & 2.8 & 0.1 & 0.1 & 0.0 & 0.0 & 0.0 & 0.0 & 0.4 & 0.9 & 0.1 \\
\hline 4 & 58.6 & 0.6 & 0.0 & 0.0 & 0.0 & 0.5 & 0.1 & 54.5 & 0.0 & 0.3 \\
\hline 5 & 1197.5 & 11.7 & 0.5 & 0.0 & 0.0 & 8.9 & 2.3 & 1101.7 & 0.0 & 31.2 \\
\hline 6 & 67.6 & 0.0 & 0.0 & 0.0 & 0.0 & 0.0 & 0.0 & 0.0 & 0.0 & 0.0 \\
\hline 7 & 5.0 & 4.4 & 0.6 & 3.0 & 0.0 & 0.3 & 0.5 & 0.1 & 0.1 & 0.0 \\
\hline Итого & 2337.5 & 781.4 & 496.1 & 105.5 & 8.3 & 58.7 & 112.8 & 1305.7 & 20.1 & 34.1 \\
\hline
\end{tabular}

Примечания: 1 - земли сельскохозяйственного назначения; 2 - земли населенных пунктов (поселений); 3 - земли промышленности, ...; 4 - земли особо охраняемых территорий; 5 земли лесного фонда; 6 - земли водного фонда; 7 - земли запаса; полужирным шрифтом выделены те площади, которые отнесены к растительному покрову; полужирным курсивом выделены залежи, которые могут быть преобразованы в земельные участки растительного покрова.

Критерии активности растительного покрова. Абсолютная активность растительного покрова будет оцениваться площадью $S_{P П}$, а относительная активность $\mu$ его выражением

$$
\mu=S_{\text {РП }} / S_{\text {общ }},
$$

где $S_{P \Pi}-$ площадь растительного покрова, тыс. га;

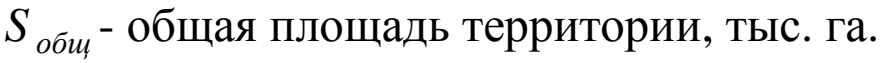

По табл. 1 получим значение абсолютной активности в виде суммы: растительный покров = многолетние насаждения на сельскохозяйственных землях + сенокосы + пастбища + земли, покрытые лесом + древеснокустарниковая растительность + болота. Количественно получаем значение $S_{P \Pi}=8,3+58,7+112,8+1305,7+20,1+34,1=1539,7$ тыс. га.

Относительная активность будет определяться по формуле (1) в виде отношения $\mu=1539,7 / 2337,5=0,659>0,618$. Таким образом, на территории РМЭ соблюдается рациональное территориальное

экологическое равновесие. Это видно из того, что коэффициент активности растительного покрова больше золотой пропорции 0,618. Другие субъекты РФ получать собственные значения активности растительного покрова. 
Залежи земель являются по своей физической сути отходами сельскохозяйственной деятельности. Самым лучшим поведением людей явится превращение залежей в растительный покров, в частности, в сенокосы и пастбища, а также в многолетние насаждения, в том числе и лесные насаждения. Такое увеличение площади растительного покрова по РМЭ на 105,5 тыс. га позволит поднять, при небольших затратах, активность растительного покрова до уровня $\mu=0,704$.

С позиций экологии более требовательным является коэффициент лесоаграрности, показывающий отношение ядра биосферы (покрытая лесом площадь) к сильно измененной человеком части территории (пашне).

Тогда получаем три значения этого лесоаграрного критерия активности растительного покрова:

- без учета залежей, которые в будущем останутся такими, постепенно природой превращаясь в закустаренные земли, а через 50-100 лет зарастут новым лесом, поэтому в этом случае $k=1305,7 / 496,1=2,632$;

- с учетом в пашне будущего освоения и залежных земель сельскохозяйственного назначения $k=1305,7 /(496,1+105,5)=2,170$;

- с учетом того, что залежи будут преобразованы в элементы растительного покрова $k=(1305,7+105,5) / 496,1=2,845$.

Значимая разница вариаций критерия показывает, что нужно обратить серьезное внимание на преобразование земельных участков из одной категории кадастра в другую. Законодательно перевод земель лесного фонда в другие категории существует. А вот обратной законодательной процедуры, чтобы сельскохозяйственные земли передавались в лесной фонд, пока нет.

Лесистость территории (коэффициент лесистости $\xi$ ) определится отношением лесной площади к общей площади, и для РМЭ он равен $\xi=1305,7 / 2337,5=0,5586$ или 55,86 \%. Распаханность территории (коэффициент распаханности $\varsigma$ ) равен отношению площади пашни к общей площади, и для РМЭ равен $\varsigma=496,1 / 2337,5=0,2122$ или 21,22 \%. 
Группировка административных образований. Рассмотрим способ группировки по признаку аграрной освоенности территории, то есть по процессу наиболее агрессивного поведения разумных животных вида Ното sapiens по коренному изменению природной среды своего обитания.

Для выработки нового методологического подхода вначале был проведен анализ доли земель сельскохозяйственного назначения в общей площади земель у 14 сельских районов (табл. 2) на 01.01.2007 год.

Из данных табл. 2 видно, что доля земель сельскохозяйственного назначения по районам РМЭ изменяется от 9,51 до 85,97 \%, где минимум приходится на самый крупный Килемарский район, а максимум - на Новоторьяльский, как десятый по крупности из 14 районов.

Таблица 2 Доля земель сельскохозяйственного назначения в общей площади (на 01.01.2007), га

\begin{tabular}{|l|r|r|r|l|r|r|r|}
\hline $\begin{array}{l}\text { Сельский район } \\
\text { и город }\end{array}$ & $\begin{array}{c}\text { Общая } \\
\text { пло- } \\
\text { щадь }\end{array}$ & $\begin{array}{c}\text { Всего с/х } \\
\text { угодий }\end{array}$ & $\begin{array}{c}\text { Доля } \\
\%\end{array}$ & $\begin{array}{c}\text { Сельский район } \\
\text { и город }\end{array}$ & $\begin{array}{c}\text { Общая } \\
\text { пло- } \\
\text { щадь }\end{array}$ & $\begin{array}{c}\text { Всего с/х } \\
\text { угодий }\end{array}$ & $\begin{array}{c}\text { Доля } \\
\%\end{array}$ \\
\hline РМЭ, тыс. га & 2337.5 & 781.4 & 33.43 & Новоторьяльский & 92009 & 73419 & 79.80 \\
\hline Волжский & 91386 & 39863 & 43.62 & Оршанский & 89649 & 56779 & 63.33 \\
\hline Горномарийский & 197146 & 57564 & 29.20 & Параньгинский & 79166 & 52318 & 66.09 \\
\hline Звениговский & 274878 & 34696 & 12.62 & Сернурский & 103208 & 84465 & $\mathbf{8 1 . 8 4}$ \\
\hline Килемарский & 309889 & 20975 & $\mathbf{6 . 7 7}$ & Советский & 139245 & 65508 & 47.05 \\
\hline Куженерский & 85283 & 53100 & 62.26 & Юринский & 204015 & 15851 & 7.77 \\
\hline Мари-Турекский & 151386 & 91885 & 60.70 & Йошкар-Ола & 9451 & 3784 & 40.04 \\
\hline Медведевский & 279706 & 64286 & 22.98 & Волжск & 2899 & 635 & 21.90 \\
\hline Моркинский & 227008 & 65749 & 28.96 & Козьмодемьянск & 1341 & 481 & 35.87 \\
\hline
\end{tabular}

На рис. 1 приведен рой (статистическая совокупность) всех точек по сельским районам и городам РМЭ.

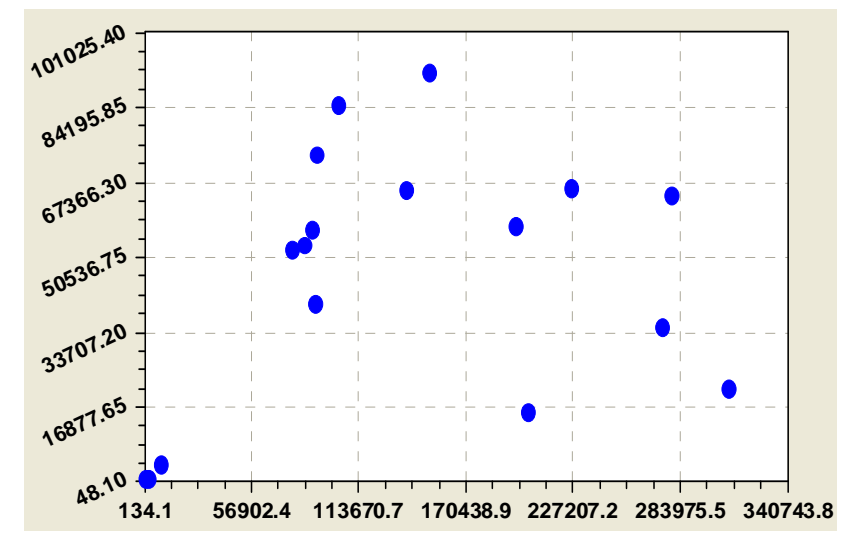

Рис. 1. Распределение площади земель сельскохозяйственного назначения относительно общей площади территорий районов и городов РМЭ

На картине четко заметна верхняя граница распределения точек, которую можно выделить как 
статистическую выборку отдельно в программной среде CurveExpert-1.3 и провести идентификацию биотехническим законом проф. П.М. Мазуркина.

Для удобства вычислений сменили масштаб данных в тыс. га. После идентификации биотехническим законом была найдена закономерность (рис. 2) взаимосвязи значений показателя площади на верхней границе роя точек

$$
S_{c / x}=0,032347 S_{\text {общ }}^{2,06038} \exp \left(-0,033343 S_{\text {общ }}{ }^{0,85041}\right),
$$

где $S_{c / x}$ - вся площадь сельскохозяйственных угодий, тыс. га;

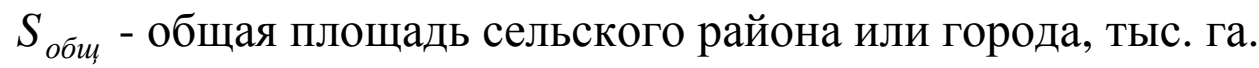

Коэффициент корреляции уравнения (2) равен 0,9987.

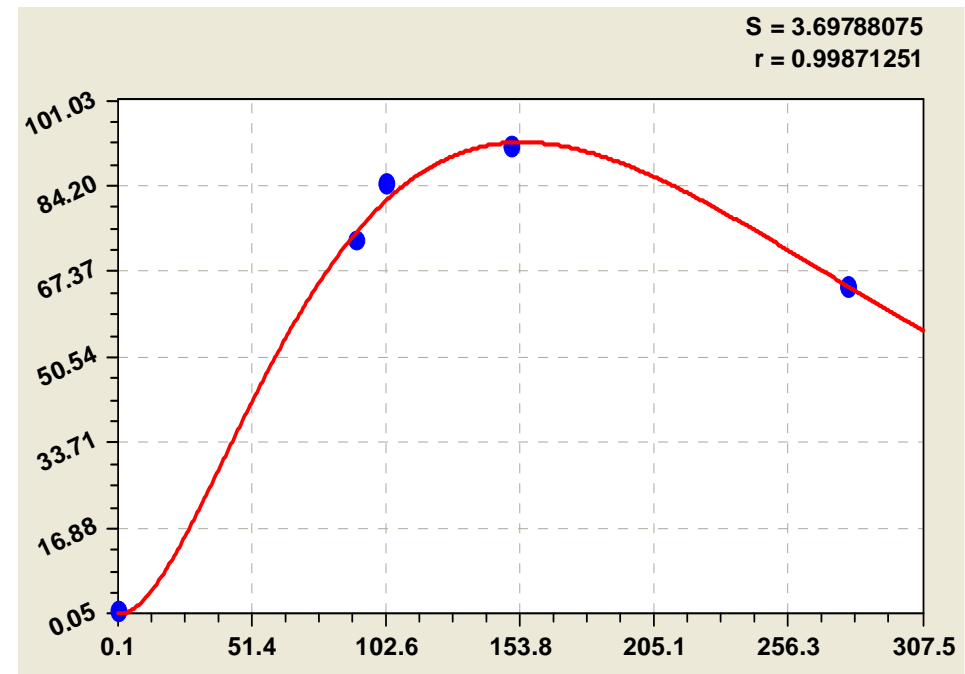

Рис. 2. Распределение площади земель сельскохозяйственного назначения относительно общей площади сельских районов и городов РМЭ по первой группе

Максимальная

относительная погрешность статистической формулы (2) равна 88,2 \% для г. Козьмодемьянска. П По

остальным точкам адекватность модели высокая.

В первую группу чрезмерной аграрной освоенности районов и городов входят Мари-Турекский, Медведевский, Новоторъяльский, Сернурский сельские районы и старинный город Козьмодемьянск.

Из оставшейся выборки во вторую группу высокой аграрной освоенности попадают семь образований, связанных формулой (рис. 3)

$$
S_{c / x}=0,035126 S_{\text {обш }}{ }^{1,91347} \exp \left(-0,021141 S_{\text {оби }}{ }^{0,90563}\right) .
$$

Конструкция закона не изменилась, а другими стали только значения параметров модели (3). Можно сделать методологический вывод о том, что совокупность административных образований является некой популяцией, приспосабливающейся к ландшафтам сельскохозяйственной деятельностью. 
Максимальная относительная погрешность формулы (3) равна 59,9 \% для г. Волжска. А для Йошкар-Олы погрешность равна 41,9\%.

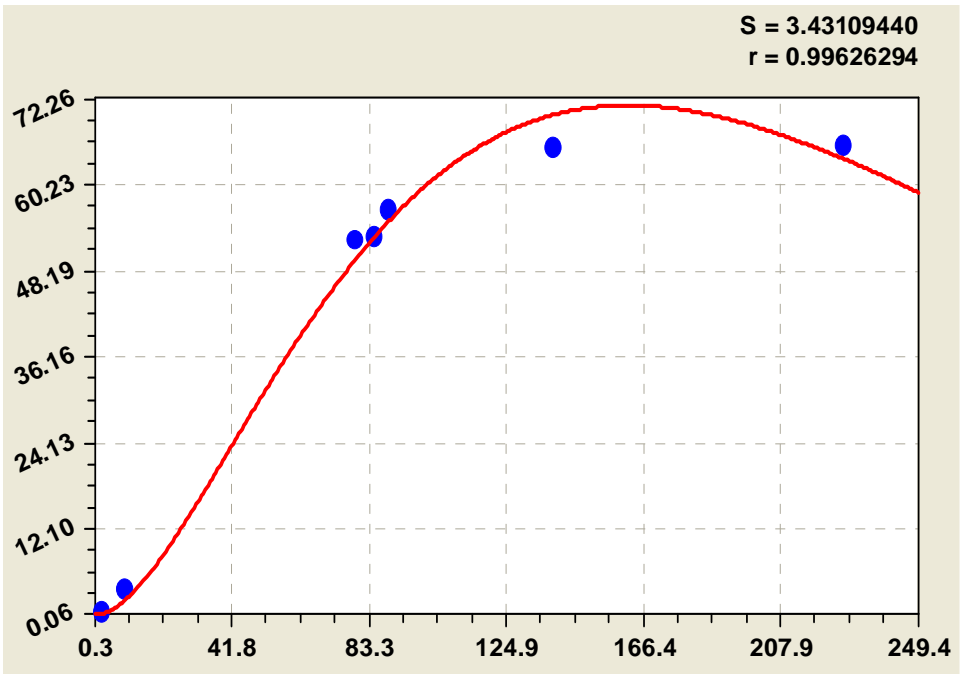

Рис. 3. Распределение площади земель сельскохозяйственного назначения относительно общей площади сельских районов и городов РМЭ по второй группе

По остальным точкам адекватность модели высокая. Значимые остатки для городов указывают на то, что урбанизацию можно учесть переменной, например плотностью населения.

Во вторую группу входят сельские районы Куженерский, Моркинский, Оршанский, Параньгинский, Советский, города Йошкар-Ола и Волжск.

Третья группа (средней аграрной освоенности) содержит четыре территории Волжского, Горномарийского, Звениговского и Килемарского сельских районов и характеризуется (рис. 4) уравнением

$$
S_{c / x}=0,00041390 S_{\text {оби, }}^{2,77161} \exp \left(-0,0031685 S_{\text {оби, }}^{1,28352}\right) .
$$

Уравнение (4) показывает известный с XIX века закон убывающей доходности Гуттенберга [2] для сельского хозяйства. Максимальная относительная погрешность равна 7,55 \% для Килемарского района.

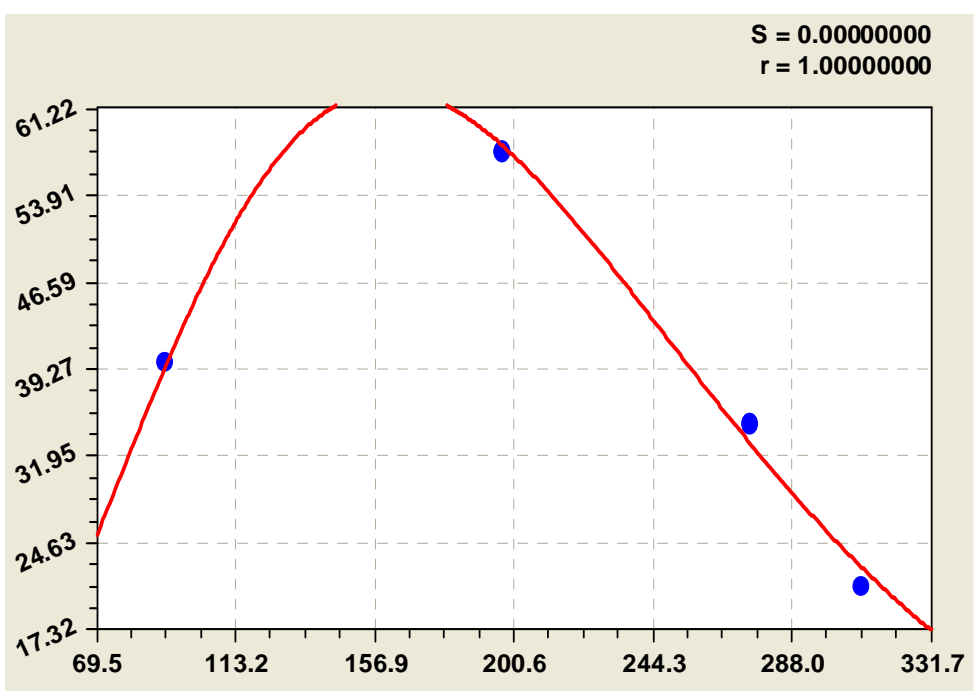

Юринский район малой аграрной освоенности имеет низкую площадь угодий. Поэтому возможно превращение ландшафтов в рекреационную зону.

Рис. 4. Распределение площади земель сельскохозяйственного назначения относительно общей площади сельских районов и городов по третьей группе 
Как примеры из 14 районов РМЭ рассмотрим два сельских района.

Чрезмерно освоенные земли. Вышеприведенные два критерия (коэффициент относительной активности и коэффициент лесоаграрности) позволяют оценивать состояние территории на данный момент времени, а затем измерять расстояние от золотой пропорции. Нормативную активность для конкретной территории нужно изучать, в первом приближении надо воспользоваться рекомендациями Н.Ф. Реймерса [3, с.430].

По земельным кадастрам в разрезе всех административных районов РМЭ, по данным на 01.01.2007 с уточнениями от марта 2007 г., были определены параметры активности растительного покрова.

Мари-Турекский район. Эта территория имеет данные табл. 3.

Территория не имеет залежей и в сельском хозяйстве ведет себя без образования земельных отходов. По данным табл. 3 имеется 69796 га растительного покрова при относительной его активности, без учета залежей пашенных земель, $\mu=69796 / 151386=0,461<<0,618$.

Значение коэффициента активности значительно ниже золотой пропорции. Поэтому для территории этого района РМЭ нужна программа восстановительных мер (природоприближенного обустройства).

Таблица 3

Данные земельного кадастра по Мари-Турекскому району РМЭ на 01.01.2007, га

\begin{tabular}{|c|c|c|c|c|c|c|c|c|c|c|}
\hline \multirow{2}{*}{$\begin{array}{c}\text { Кате- } \\
\text { гория } \\
\text { земель }\end{array}$} & \multirow{2}{*}{$\begin{array}{c}\text { Общая } \\
\text { пло- } \\
\text { щадь }\end{array}$} & \multirow{2}{*}{$\begin{array}{l}\text { Всего } \\
\text { с/х } \\
\text { угодий }\end{array}$} & \multicolumn{5}{|c|}{ В том числе: } & \multirow{2}{*}{$\begin{array}{c}\text { Земли, } \\
\text { покрыт. } \\
\text { лесом }\end{array}$} & \multirow{2}{*}{$\begin{array}{c}\text { Древес. } \\
\text { кустарн. } \\
\text { растит. }\end{array}$} & \multirow[b]{2}{*}{ Болота } \\
\hline & & & Пашни & Залежи & $\begin{array}{l}\text { Мн.лет. } \\
\text { насажд. }\end{array}$ & $\begin{array}{l}\text { Сено- } \\
\text { косы }\end{array}$ & $\begin{array}{l}\text { Паст- } \\
\text { бища }\end{array}$ & & & \\
\hline 1 & 99720 & 88070 & 72815 & 0 & \begin{tabular}{|l|}
74 \\
\end{tabular} & 6299 & 8882 & 7391 & 1275 & 34 \\
\hline 2 & 5331 & 3613 & 3121 & 0 & 76 & 416 & 0 & 138 & 181 & 1 \\
\hline 3 & 559 & 0 & 0 & 0 & 0 & 0 & 0 & 0 & 69 & 0 \\
\hline 4 & 0 & 0 & 0 & 0 & 0 & 0 & 0 & 0 & 0 & 0 \\
\hline 5 & 45776 & 202 & 42 & 0 & 0 & 160 & 0 & 44785 & 0 & 15 \\
\hline 6 & 0 & 0 & 0 & 0 & 0 & 0 & 0 & 0 & 0 & 0 \\
\hline 7 & 0 & 0 & 0 & 0 & 0 & 0 & 0 & 0 & 0 & 0 \\
\hline Итого & 151386 & 91885 & 75978 & 0 & 150 & 6875 & 8882 & 52314 & 1525 & 50 \\
\hline
\end{tabular}

Примечание: Расшифровка категорий земель приведена под табл. 5.1.

Коэффициент лесоаграрности $k=52314 / 75978=0,689$. Лесистость равна $\xi=52314 / 151386=0,3456$, а распаханность составляет $\varsigma=75978 / 85283=0,8909$. 
Медведевский район. Он окружает столицу РМЭ г. Йошкар-Олу своими землями и эта территория имеет данные табл. 4.

Таблица 4

Данные земельного кадастра по Медведевскому району РМЭ на 01.01.2007, га

\begin{tabular}{|c|c|c|c|c|c|c|c|c|c|c|}
\hline \multirow{2}{*}{$\begin{array}{c}\text { Кате- } \\
\text { гория } \\
\text { земель }\end{array}$} & \multirow{2}{*}{$\begin{array}{c}\text { Общая } \\
\text { пло- } \\
\text { щадь }\end{array}$} & \multirow{2}{*}{$\begin{array}{l}\text { Всего } \\
\text { с/х } \\
\text { угодий }\end{array}$} & \multicolumn{5}{|c|}{ В том числе: } & \multirow{2}{*}{$\begin{array}{c}\text { Земли, } \\
\text { покрыт. } \\
\text { лесом }\end{array}$} & \multirow{2}{*}{$\begin{array}{l}\text { Древес. } \\
\text { кустарн } \\
\text { растит. }\end{array}$} & \multirow[b]{2}{*}{ Болота } \\
\hline & & & Пашни & Залежи & \begin{tabular}{|l|} 
Мн.лет. \\
насажд.
\end{tabular} & $\begin{array}{l}\text { Сено- } \\
\text { косы }\end{array}$ & $\begin{array}{l}\text { Паст- } \\
\text { бища }\end{array}$ & & & \\
\hline 1 & 70080 & 58057 & 36895 & 0 & \begin{tabular}{|l|}
3369 \\
\end{tabular} & 7325 & 10468 & 6059 & \begin{tabular}{|l|}
868 \\
\end{tabular} & 223 \\
\hline 2 & 6779 & 4596 & 3682 & 0 & 111 & 177 & 626 & 97 & 36 & 0 \\
\hline 3 & 15093 & 398 & 46 & 0 & 0 & 237 & 115 & 10957 & 242 & 0 \\
\hline 4 & 15057 & 112 & 0 & 0 & 0 & 112 & 0 & 14503 & 0 & 29 \\
\hline 5 & 171876 & 897 & 31 & 0 & 0 & 728 & 138 & 159637 & 0 & 2827 \\
\hline 6 & 181 & 0 & 0 & 0 & 0 & 0 & 0 & 0 & 0 & 0 \\
\hline 7 & 640 & 226 & 156 & 0 & 0 & 32 & 38 & 5 & 0 & 1 \\
\hline Итого & 279706 & 64286 & 40810 & 0 & 3480 & 8611 & 11385 & 191258 & 1151 & 3080 \\
\hline
\end{tabular}

Этот район не имеет залежей и в сельском хозяйстве пока ведет себя также без образования земельных отходов. По данным табл. 4 имеется 220965 га растительного покрова при $\mu=220965 / 279706=0,790>>0,618$.

Значение коэффициента активности значительно выше золотой пропорции. Такой растительный покров успешно выполняет функции легких столицы марийского края. По коэффициенту лесоаграрности было получено значение активности растительного покрова $k=191258 / 40810=4,687$. Лесистость Медведевского района равна $\xi=191258 / 279706=0,6838$, а распаханность земель составляет $\varsigma=40810 / 279706=0,1459$.

Активность городской растительности. На территории РМЭ находятся три города: столица Йошкар-Ола и города Волжск и Козьмодемьянск. Методика анализа экологического состояния по активности растительного покрова аналогична сельским районам. Урбанизация как природно-техногенный процесс выявляется через учет плотности населения.

Йошкар-Ола. Исходные данные земельного кадастра по состоянию на 01.01.2007 приведены в табл. 5.

На территории г. Йошкар-Ола находится 2455 гектаров растительного покрова при относительной его активности $\mu=2455 / 9451=0,260<<<0,618$. 
Данные земельного кадастра по городу Йошкар-Оле на 01.01.2007, га

\begin{tabular}{|c|c|c|c|c|c|c|c|c|c|c|}
\hline \multirow{2}{*}{$\begin{array}{c}\text { Кате- } \\
\text { гория } \\
\text { земель }\end{array}$} & \multirow{2}{*}{$\begin{array}{c}\text { Общая } \\
\text { пло- } \\
\text { щадь } \\
\end{array}$} & \multirow{2}{*}{$\begin{array}{c}\text { Всего c/x } \\
\text { угодий }\end{array}$} & \multicolumn{5}{|c|}{ В том числе: } & \multirow{2}{*}{$\begin{array}{c}\text { Земли, } \\
\text { покрыт. } \\
\text { лесом }\end{array}$} & \multirow{2}{*}{$\begin{array}{l}\text { Древес. } \\
\text { кустарн. } \\
\text { растит. }\end{array}$} & \multirow[b]{2}{*}{ Болота } \\
\hline & & & Пашни & Залежи & \begin{tabular}{|l|} 
Мн.лет. \\
насажд.
\end{tabular} & $\begin{array}{l}\text { Сено- } \\
\text { косы }\end{array}$ & $\begin{array}{l}\text { Паст- } \\
\text { бища }\end{array}$ & & & \\
\hline 1 & 2712 & 2381 & 2030 & 0 & 0 & 105 & 246 & 0 & 89 & 0 \\
\hline 2 & 5821 & 1392 & 468 & 0 & 625 & 286 & 13 & 685 & 70 & 8 \\
\hline 3 & 571 & 0 & 0 & 0 & 0 & 0 & 0 & 0 & 0 & 0 \\
\hline 4 & 0 & 0 & 0 & 0 & 0 & 0 & 0 & 0 & 0 & 0 \\
\hline 5 & 347 & 11 & 1 & 0 & 0 & 10 & 0 & 317 & 0 & 1 \\
\hline 6 & 0 & 0 & 0 & 0 & 0 & 0 & 0 & 0 & 0 & 0 \\
\hline 7 & 0 & 0 & 0 & 0 & 0 & 0 & 0 & 0 & 0 & 0 \\
\hline Итого & 9451 & 3784 & 2499 & 0 & 625 & 401 & 259 & 1002 & 159 & 9 \\
\hline
\end{tabular}

Требование золотой пропорции площади растительного покрова сохранится и для урбанизированных территорий. Не имея зеленых насаждений на земельных участках, в Токио давно стали осваивать растительным покровом крыши домов. В городах Германии зеленый покров расширяют за счет озеленения мостов и тротуаров клумбами.

Преобразование пашни в растительный покров даст увеличение коэффициента активности до уровня $\mu=(2455+2499) / 9451=0,524<0,618$. Следующей мерой станет уменьшение ширины пешеходных тротуаров, а также снижение площади под места парковки автомобилей. Таких преобразований асфальтированных земель в г. Йошкар-Оле будет достаточно. Чтобы добиться золотой пропорции, необходимо будет выделить дополнительно площадь под растительный покров 0,618 х 9451 - 2455 - 2499 $=887$ га из второй категории земель поселений при сносе ветхих строений.

Коэффициент лесоаграрности равен $k=1002 / 2499=0,401$. Город Йошкар-Ола выглядит экологичнее по сравнению с Сернурским районом. Лесистость $\xi=1002 / 9451=0,1060$, а распаханность $\varsigma=2499 / 9451=0,2644$.

Ранговое распределение административных образований. По четырем коэффициентам распределение сельских районов и городов РМЭ приведено в табл. 6. Рядом расставлены ранги значений этих показателей.

Активность растительного покрова изменяется (рис. 5) по формуле

$$
\mu=0,87233 \exp \left(-0,030549 r_{\mu}^{1,42556}\right) \text {. }
$$


На рис. 5 видны небольшие колебания параметра территории, однако они малозначимы. Поэтому тренд (5) может быть принят за закономерность, показывающую ранговое распределение административных территорий.

Ранговые распределения административных образований РМЭ

Таблица 6

\begin{tabular}{|c|c|c|c|c|c|c|c|c|}
\hline \multirow{3}{*}{$\begin{array}{c}\text { Образование } \\
\text { административное } \\
\text { субъекта федерации }\end{array}$} & \multicolumn{8}{|c|}{ Коэффициенты активности растительного покрова по: } \\
\hline & \multicolumn{2}{|c|}{ активности } & \multicolumn{2}{|c|}{ лесоаграрности } & \multicolumn{2}{|c|}{ лесистости } & \multicolumn{2}{|c|}{ распаханности } \\
\hline & $\mu$ & $r_{\mu}$ & $k$ & $r_{k}$ & $\xi$ & $r_{\xi}$ & $\varsigma$ & $r_{\varsigma}$ \\
\hline Республика Марий Эл & 0.659 & - & 2.632 & - & 0,5586 & - & 0.2122 & - \\
\hline Волжский район & 0.557 & 6 & 1.474 & 7 & 0.4298 & 7 & 0.2916 & 8 \\
\hline Горномарийский р-н & 0.570 & 5 & 2.195 & 5 & 0.4592 & 6 & 0.2092 & 6 \\
\hline Звениговский район & 0.826 & 1 & 8.436 & 2 & 0.7558 & 2 & 0.0896 & 3 \\
\hline Килемарский район & 0.878 & 0 & 49.891 & 0 & 0.8266 & 0 & 0.0166 & 0 \\
\hline Куженерский район & 0.420 & 11 & 0.678 & 9 & 0.3158 & 9 & 0.4655 & 13 \\
\hline Мари-Турекский р-н & 0.461 & 9 & 0.689 & 8 & 0.3456 & 8 & 0.8909 & 16 \\
\hline Медведевский район & 0.790 & 3 & 4.687 & 4 & 0.6838 & 3 & 0.1459 & 5 \\
\hline Моркинский район & 0.769 & 4 & 5.634 & 3 & 0.6553 & 4 & 0.1163 & 4 \\
\hline Новоторъяльский р-н & 0.274 & 12 & 0.343 & 12 & 0.1299 & 12 & 0.3789 & 11 \\
\hline Оршанский район & 0.437 & 10 & 0.679 & 9 & 0.2902 & 10 & 0.4273 & 12 \\
\hline Параньгинский район & 0.472 & 7 & 0.583 & 10 & 0.2820 & 11 & 0.4840 & 14 \\
\hline Сернурский район & 0.261 & 13 & 0.222 & 13 & 0.1142 & 13 & 0.5138 & 15 \\
\hline Советский район & 0.542 & 7 & 1.543 & 6 & 0.4754 & 5 & 0.3081 & 10 \\
\hline Юринский район & 0.799 & 2 & 31.805 & 1 & 0.7620 & 1 & 0.0240 & 1 \\
\hline г. Йошкар-Ола & 0.260 & 13 & 0.401 & 11 & 0.1060 & 14 & 0.2644 & 7 \\
\hline г. Волжск & 0.184 & 15 & 0.183 & 15 & 0.0148 & 16 & 0.0811 & 2 \\
\hline г. Козьмодемьянск & 0.213 & 14 & 0.202 & 14 & 0.0611 & 15 & 0.3028 & 9 \\
\hline
\end{tabular}

Примечание: $r$ - ранг, причем $r=0,1,2, \ldots$, расположенный по ухудшению показателя.

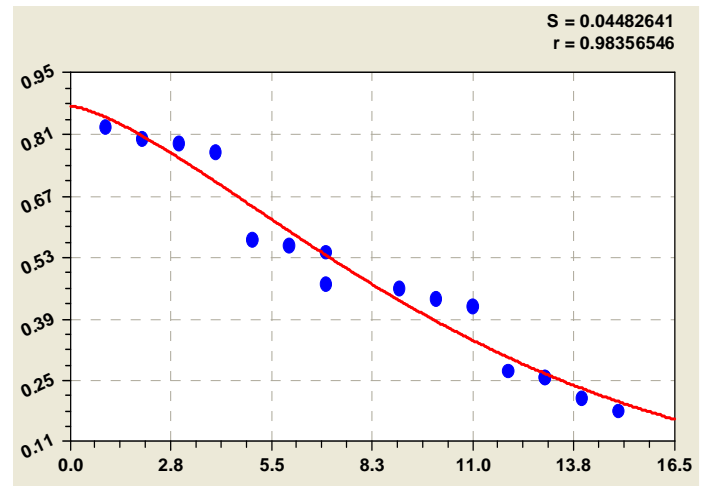

Рис. 5. Распределение коэффициента активности растительного покрова административных образований РМЭ

Весьма требовательный экологический показатель лесоаграрности (рис. 6) характеризуется формулой

$$
k=50,3257 \exp \left(-0,51939 r_{k}^{1,45224}\right) .
$$

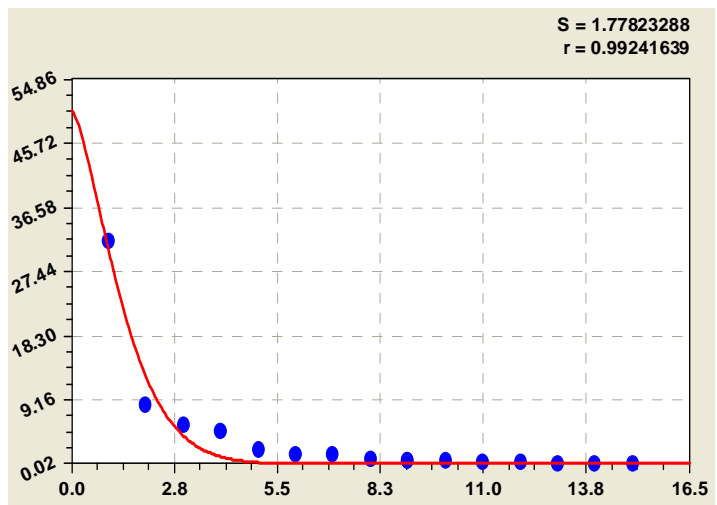

Рис. 6. Распределение коэффициента лесоаграрности территории административных образований РМЭ

Резко выделяются первые пять рангов от 0 до 4. Сразу же заметим, что 
наиболее экологичным из 17 образований РМЭ является Килемарский сельский район, имеющий по всем четырем параметрам нулевые ранги.

Людям нужно научиться жить цивилизованно на лесистых землях. Этому научились в передовых европейских и других странах. Но в России обязательно нужно уничтожать леса и распахать их на пашни.

По данным табл. 6 была получена (рис. 7) формула

$$
\xi=0,80858 \exp \left(-0,028672 r_{\xi}^{1,61510}\right) .
$$

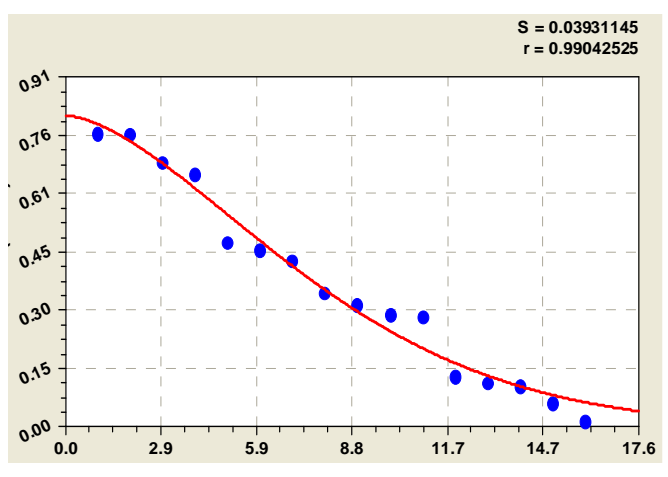

Рис. 7. Распределение коэффициента лесистости территории административных образований РМЭ

С возрастанием распаханности экологическое качество ухудшается. Поэтому ранги расставлены по сравнению с предыдущими параметрами в обратном порядке, то есть по возрастанию значений изучаемого показателя.

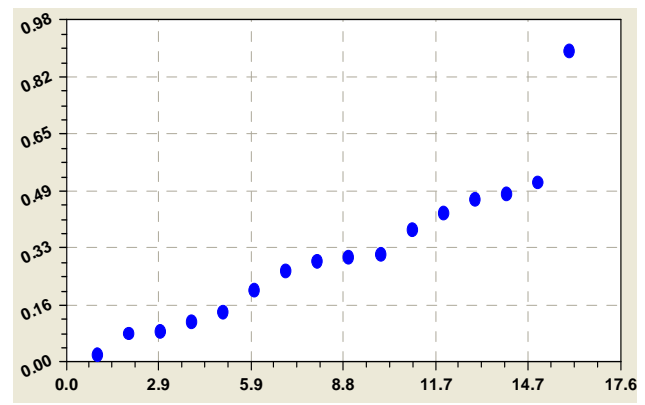

Рой точек статистической выборки приведен на рис. 8.

Рис. 8. Точечное распределение коэффициента распаханности территории административных образований РМЭ

Последняя точка резко поднимается вверх, отрываясь от общей группы. Это - чрезмерно распаханная территория Мари-Турекского сельского района. Её распаханность почти в два раза выше предыдущего Сернурского района. Поэтому крайнюю точку исключаем из группы.

Коэффициент распаханности территории изменяется по биотехническому закону (рис. 9) П.М. Мазуркина [4-7] в виде формулы

$$
\varsigma=0,0166+0,018949 r_{\varsigma}^{1,35872} \exp \left(-0,027981 r_{\varsigma}^{0,98635}\right) .
$$

Первая составляющая формулы (8)является постоянным членом, и он показывает предысторию статистического ряда. Содержательный смысл 
числа 0,0166 по Килемарскому району показывает, что там, где постоянно проживают люди, на территории РМЭ распаханность не может быть ниже $1,66 \%$ от общей площади территории.

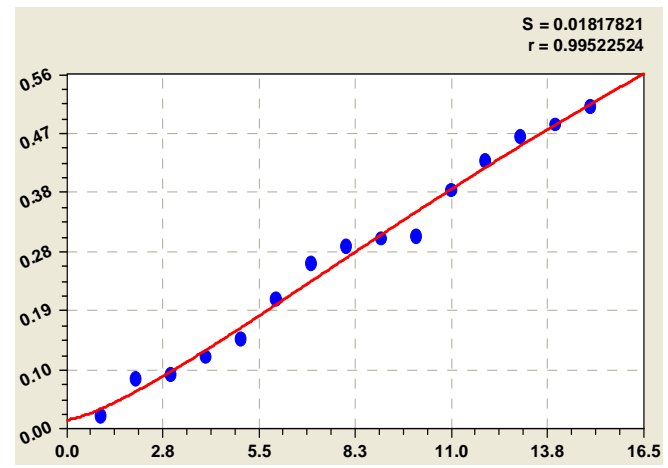

Рис. 9. Распределение коэффициента распаханности территории административных образований РМЭ

(без Мари-Турекского сельского района)

По второй закономерности можно определить для территории РМЭ предельно возможное максимальное значение коэффициента распаханности $\varsigma_{\max }=1,0000$, то есть $100 \%$, при значении объясняющей переменной $r_{s}=52$. Однако фактически ранг распаханности по данным табл. 6 достигает только значения 16.

Экологичность территории. По совокупности четырех параметров можно судить об экологичности каждого административного образования.

Простейшим способом является определение места $I$ по сумме рангов $r$ всех учтенных показателей $\mu, k, \xi, \varsigma$.

Сводные данные по всем четырем рангам приведены в табл. 7.

Таблица 7

Места административных образований по экологичности на территории РМЭ

\begin{tabular}{|c|c|c|c|c|c|c|}
\hline \multirow{2}{*}{$\begin{array}{c}\text { Сельский район } \\
\text { или город } \\
\text { Республики Марий Эл }\end{array}$} & \multicolumn{4}{|c|}{ Ранги активности растительного покрова } & \multirow{2}{*}{$\begin{array}{l}\text { Сумма } \\
\text { рангов }\end{array}$} & \multirow{2}{*}{$\begin{array}{l}\text { Место по } \\
\text { эколо- } \\
\text { гичности }\end{array}$} \\
\hline & $r_{\mu}$ & $r_{k}$ & $r_{\xi}$ & $r_{\varsigma}$ & & \\
\hline Волжский район & 6 & 7 & 7 & 8 & 28 & 6 \\
\hline Горномарийский р-н & 5 & 5 & 6 & 6 & 22 & 5 \\
\hline Звениговский район & 1 & 2 & 2 & 3 & 8 & 3 \\
\hline Килемарский район & 0 & 0 & 0 & 0 & 0 & 1 \\
\hline Куженерский район & 11 & 9 & 9 & 13 & 42 & 8 \\
\hline Мари-Турекский р-н & 9 & 8 & 8 & 16 & 41 & 7 \\
\hline Медведевский район & 3 & 4 & 3 & 5 & 15 & 4 \\
\hline Моркинский район & 4 & 3 & 4 & 4 & 15 & 4 \\
\hline Новоторъяльский р-н & 12 & 12 & 12 & 11 & 47 & 11 \\
\hline Оршанский район & 10 & 9 & 10 & 12 & 41 & 7 \\
\hline Параньгинский район & 7 & 10 & 11 & 14 & 42 & 8 \\
\hline Сернурский район & 13 & 13 & 13 & 15 & 52 & 13 \\
\hline Советский район & 7 & 6 & 5 & 10 & 28 & 6 \\
\hline Юринский район & 2 & 1 & 1 & 1 & 5 & 2 \\
\hline г. Йошкар-Ола & 13 & 11 & 14 & 7 & 45 & 10 \\
\hline г. Волжск & 15 & 15 & 16 & 2 & 48 & 12 \\
\hline г. Козьмодемьянск & 14 & 14 & 7 & 9 & 44 & 9 \\
\hline
\end{tabular}


По данным табл. 7 первое место по экологичности территории занимает Килемарский район, а на последнем 13-ом месте вгруппе находится Сернурский сельский район.

\section{Литература}

1. Уфимцева, М.Д. Фитоиндикация экологического состояния урбоэкосистем СанктПетербурга / М.Д. Уфимцева, Н.В. Терехина. - СПб.: Наука, 2005. - 339 с.

2. Вёйе, Г. Введение в общую экономику и организацию производства. Часть $1 /$ Г. Вёйе, У. Дёринг. - Красноярск: Изд-во Краснояр. ун-та, 1995. - 497 с.

3. Реймерс, Н.Ф. Природопользование: Словарь-справочник / Н.Ф. Реймерс. - М.: Мысль, 1990. - $637 \mathrm{c}$.

4. Мазуркин, П.М. Лесистость и распаханность территории / П.М. Мазуркин, С.И. Васильева // Экология: Образование, наука, промышленность и здоровье: материалы II Международной научно-практической конференции. - Вестник БГТУ. - 2004. - №8.. Часть V. - C.83-85.

5. Мазуркин, П.М. Закономерности кадастровой оценки сельскохозяйственных угодий (на примере Республики Марий Эл) / П.М. Мазуркин, Г.Н. Ильменев, Ф.Н. Салахутдинов: Научное издание. - Йошкар-Ола: МарГТУ-ФГУП МарГипрозем, 2002. $66 \mathrm{c}$.

6. Мазуркин, П.М. Закономерности распределения земельного фонда (на примере Республики Марий Эл): Научное издание / П.М. Мазуркин, А.Н. Фадеев. - Йошкар-Ола: МарГТУ, 2006. - 127 с.

7. Мазуркин, П.М. Математическое моделирование. Идентификация однофакторных статистических закономерностей: Учебное пособие / П.М. Мазуркин, А.С. Филонов. Йошкар-Ола: МарГТУ, 2006. - 292 с. 